\title{
Oxidative stress, inflammation and apoptosis are the main mediators in AMB-FUBINACA induced brain injury in male Albino rats
}

\author{
Asmaa F. Esawy ${ }^{1 *}$, Nadia A. Eltablawy ${ }^{2}$, Abeer I. Abd El-Fattah ${ }^{1}$ and Wesam A. Abdelwahab ${ }^{3}$
}

\begin{abstract}
${ }^{1}$ Department of Biochemistry and Molecular Biology, Faculty of Pharmacy (Girls), Al-Azhar University Cairo, Egypt.
${ }^{2}$ Department of Biochemistry, National Organization for Drug and Control Research (NODCAR, currently Egyptian drug authority, EDA) Cairo, Egypt.

${ }^{3}$ Department of Forensic Medicine and Clinical Toxicology, Faculty of Medicine (Girls), Al-Azhar University Cairo, Egypt.

* Corresponding Author: dr.asmaaesawy@gmail.com
\end{abstract}

Article history: Received 2021/06/30 Revised 28-07-2021 $\quad$ Accepted 2021/07/31

\begin{abstract}
Synthetic cannabinoids (SCs) abuse is a serious social problem worldwide. It can cause severe toxicity, including seizures and even death. This study aims to examine the role of sub-chronic administration of AMB-FUBINACA SC in the induction of brain injury. 32 Male adult rats divided into four groups (8 rats per cage) were used, Control group: Intraperitoneally (IP) injected with $0.5 \mathrm{ml}$ of the vehicle, and the others each one of them IP injected with $0.5 \mathrm{ml}$ of the three different doses of AMB-FUBINACA as following: Group1: $1 \mathrm{mg} / \mathrm{kg}$, Group 2: $3 \mathrm{mg} / \mathrm{kg}$ and Group 3: $4 \mathrm{mg} / \mathrm{kg}$. The drug was injected once a day for six consecutive days. Tremors were observed 30 minutes following drug injection especially with 3 and $4 \mathrm{mg} / \mathrm{kg}$ examined doses followed by depressant effect. Then rats became hyperactive and aggressive. The drug administration induced a significant disturbance in the redox status of brain and significantly increased tumor necrosis factor- $\alpha$ (TNF- $\alpha$ ), interlukin-6 (IL-6) and the soluble calcium binding protein B (S100B) serum levels. In addition, the mRNA expression levels of nuclear factor kappa $\mathrm{B}(\mathrm{NF}-\kappa \mathrm{B})$, mitogen activated protein kinase p38 (MAPK p38) and Caspase-3 were significantly up-regulated. Meanwhile, the mRNA expression levels of Cannabinoid receptors (CB1R, CB2R) and brain derived neurotrophic factor (BDNF) were significantly downregulated. The obtained results demonstrated that, AMB-FUBINACA harmful effects increase with the dose, which was supported by the brain histopathological examination. We concluded that, AMB-FUBINACA has a functional and structural deleterious central nervous system (CNS) effects with sub chronic exposure in adult male rats. The induced brain injury and seizures that accompanied with the synthetic cannabinoids abuse might be mediated through the generation of oxidative stress, activating inflammatory cellular signaling mechanism and neural cell death via apoptosis.
\end{abstract}

Keywords: Oxidative stress, Inflammation, Caspase-3 and Synthetic Cannabinoids

This is an open access article distributed under the CC BY-NC-ND license https://creativecommons.org/licenses/by/4.0/

\section{INTRODUCTION}

Synthetic Cannabinoids considered the biggest class of new psychoactive substances (NPS) reported by the European monitoring center for drugs and drug addiction (EMCDDA) recently. ${ }^{1}$ Poisoning cases and ultimately death are relevant among the users of these substances. ${ }^{2-5}$ SCs were firstly, synthesized for curative goals, but nowadays, some workrooms produce them as recreational substances, where it is treated with organic solvents and combined with dry plants to give the impress of being natural; or condensed in tablet for oral consumption. ${ }^{\mathbf{6}, 7}$

Oxidative stress can be considered as an important underlying cause of cannabinoid toxicity. ${ }^{\mathbf{2}}$ Reactive oxygen species (ROS) accumulation leads to oxidative stress due to the pro-oxidant-antioxidant balance gets disturbed. The disturbance in this redox equilibrium causes severe irreversible interruption to the normal functions of cells, thereby affecting the entire system. ${ }^{9,10}$ ROS has a great effect in brain pathology in the context of neurology ${ }^{\mathbf{1 1}}$ such as stroke which is

Cite this article: Esawy, A., Eltablawy, N., Abd El-Fattah, A., Abdalwahab, W. Oxidative stress, inflammation and apoptosis are 82 the main mediators in AMB-FUBINACA induced brain injury in male Albino Rats. Azhar International Journal of Pharmaceutical and Medical Sciences, 2022; 2(1):82 -95. doi: 10.21608/aijpms.2022.210570

DOI : 10.21608 /aijpms.2022.210570 
a famous toxic effect of cannabinoid use, as shown in several studies. ${ }^{12-14}$ ROS accumulation is also implicated in behavioral changes such as anxiety, depression and memory impairments. ${ }^{\mathbf{1 5}}$

Free radicals also trigger neuron inflammation through the up-regulated production of proinflammatory factors as cytokines and chemokines. These factors, especially tumor necrosis factor- $\alpha$ (TNF- $\alpha$ ) which is one of the main protein involved in an inflammatory and immune response that is associated with the up-regulation and expression of other cytokines, such as interlukin-6 (IL-6) in microglial cells, astrocytes, leukocytes and endothelial cells as part of a response to brain damage leading to the loss of synapses, neuronal death, and consequently cognitive dysfunction. ${ }^{\mathbf{1 6}, 17}$ Therefore neuron inflammation and the accumulation of these oxidative modified proteins in the brain enhance neuronal degeneration. ${ }^{18,19,20}$

It has been demonstrated that TNF- $\alpha$ stimulates brain pericytes to increase the synthesis of IL- 6 by activating nuclear factor kappa $\mathrm{B}(\mathrm{NF}-\kappa \mathrm{B})^{\mathbf{2 1}}$, where NF-kB activation in the mitochondria leads to cytochrome $\mathrm{c}$ release, thus triggering caspase cascades and programed cell death. ${ }^{19}$ Also the release of pro-inflammatory cytokines trigger mitogen activated protein kinase p38 (MAPK p38) pathway activation ${ }^{22}$, which participate in the regulation of a variety of cellular processes, including cell proliferation, differentiation, and apoptosis. $^{23}$ Thus the enhancement of proinflammatory cytokines produces aggression and contributes to neuronal apoptosis and memory impairment through Caspase-3 pathway, ${ }^{\mathbf{2 0}}$ which is an enzymes crucial for initiation and execution of apoptosis within a cell and plays a key role in cleavage of cytoskeletal proteins that can further contribute to chronic axonal and microvascular damage. ${ }^{24,25}$

Brain derived neurotrophic factor (BDNF) is a member of the neurotrophin family that has a wide array of functions within the brain. It is involved in plasticity, neuronal survival, formation of new synapses, and dendritic branching, as well as modulation of excitatory and inhibitory neurotransmitter profiles. Many brain pathologies cause reduction of BDNF protein levels both in the brain and serum of patients. ${ }^{26} \mathrm{~S} 100 \mathrm{~B}$, is a calcium sensor protein, appears to regulate a variety of activities, transferring signals from second messengers and interacting with different molecules in different cell types. Serum S100B level as well, is a marker of brain injury and damage and found to be increased in a variety of pathological conditions of the nervous system. ${ }^{27}$
An indazole-3-carboxamide SC called AMBFUBINACA appeared 2014 in Sweden. It is one of the most widely abused NPS. ${ }^{28}$ It is mainly marketed as a more potent substitutes of cannabis through the internet. ${ }^{29}$ It has more cannabinoid receptors affinity and thus potency than trans- $\Delta 9$ tetrahydrocannabinol $(\triangle 9-\mathrm{THC}) .^{\mathbf{3 0 - 3 2}}$ AMBFUBINACA causes more intense psychotropic effects and increased severity of the cardiovascular (CVC) and neurological toxicities, in relation to $\Delta 9$ THC, even with the consumption of small amounts ${ }^{33,34}$ through the activation of cannabinoids receptors. A "zombie outbreak" - was reported as a hallmark of AMB-FUBINACA toxicity. ${ }^{35,2}$ Yet, the knowledge of toxicological mechanisms of AMBFUBINACA remains unclear, therefore this work was performed to explore the impact of this drug in the induction of brain cellular injury, through the characterization of inflammation, oxidative stress and neural cell death in experimental animals.

\section{METHODS}

\subsection{AMB-FUBINACA}

AMB-FUBINACA was kindly obtained from the Forensic chemistry Laboratories, Forensic Medicine Authorization (Cairo, Egypt) after permission from the Ministry of Justice. AMB-FUBINACA was confirmed by GC-MS. It is dissolved in absolute ethanol, Cremophor EL, and saline solution $(1: 1: 18)$. The vehicle was prepared as solution made of ethanol, Cremophor EL, and saline. ${ }^{36}$

\subsection{Experimental design}

Study was performed on 32 male Wister rats, weighing 120 - $140 \mathrm{~g}$. Animals were allowed free access of food and water, maintained at about $22^{\circ} \mathrm{C}$, pathogen free animal house. They were classified into four groups (8 rats per cage), Control group: IP injected with $0.5 \mathrm{ml}$ of the vehicle, and the others each IP injected with $0.5 \mathrm{ml}$ of the three different doses of freshly prepared AMB-FUBINACA in vehicle used as following: Group1: $1 \mathrm{mg} / \mathrm{kg}$, Group 2: $3 \mathrm{mg} / \mathrm{kg}$ and Group 3: $4 \mathrm{mg} / \mathrm{kg}$. The doses were chosen according to Canaza et al. ${ }^{37}$. All groups were received the treatment once a day for six consecutive days and were observed in their cages daily throughout the study for seizures and aggressiveness.

\subsection{Sampling}

After AMB-FUBINACA last dose by 24 hours, all animals were lightly anaesthetized with diethyl ether inhalation. Blood was collected, left to clot and separated for measurement of S100B, TNF- $\alpha$ and 
IL-6 levels. Animals were sacrificed by cervical dislocation while they were under anesthesia. Brains then removed and cut into three partitions. One fixed in formalin for the histopathological examination, and the other two halves were homogenized in different buffers for undergoing two different techniques of parameters estimation: The first half was reserved for malondialdehyde (MDA) and reduced glutathione (GSH) determination. The second one was reserved for the quantitative estimation of brain CB1R, CB2R, BDNF, MAPK, $\mathrm{NF}-\kappa \mathrm{B}$, and Caspase-3 mRNA expression levels.

\subsection{Biochemical analysis}

\subsubsection{Estimation of S100B, TNF- $\alpha$ and IL6 serum levels}

Levels of S100B, TNF- $\alpha$ and IL-6 were measured by enzyme linked immunosorbent assay (ELISA) technique, using Mybiosource, USA (CAT. No. MBS2023945), Cusabio, China (CAT. No. CSB-E11987r) and Quantikine ${ }^{\circledR}$ R and D system, USA (CAT. No. R6000B) kits individually as directed by the manufacturers.
2.4.2 Assessment of MDA and GSH content in brain tissue

Lipid per-oxidative end product MDA and GSH content in brain tissue homogenate were assayed by colorimetric assay kits provided by Biodiagnostic, Egypt (CAT. No. MD 25 28) as directed by the manufacturers.

2.4.3 Quantitation of $m R N A$ expression levels of $C B 1 R, C B 2 R, B D N F, M A P K, N F-\kappa B$ and Caspase3 in brain tissue by quantitative real time PCR:

Qiagen tissue extraction kit was used for brain RNA isolation. Fermentas Reverse transcription kit was used for RNA reverse transcription into complementary DNA. Hasting Software was used for designing PCR primers using RNA sequences obtained from gene bank (Table 1). QuanitativeRTPCR was done by using $25 \mathrm{ml}$ reaction volume containing SYBR Green. The relative CB1R, CB2R, BDNF, MAPK, NF- $\kappa$ B and Caspase-3 mRNA expression was calculated by comparative threshold cycle method $(\mathrm{Ct})$. $\beta$-actin gene internal control was concluded, ${ }^{\mathbf{3 8}}$ and the results were reported as fold change.

Table 1. Sequence of the primers used for real-time PCR.

\begin{tabular}{|c|c|}
\hline Gene & Primer sequence \\
\hline CB1-R & $\begin{array}{l}\text { Forward, 5' CCATTTCAAGCAAGGAGCAC3' } \\
\text { Reverse, 5' GTCATTCGAGCCCACGTAGA3' }\end{array}$ \\
\hline CB2-R & $\begin{array}{c}\text { Forward, 5' GGGTCGACTCCAACGCTATC3' } \\
\text { Reverse, } \\
\text { 5' AGGTAGGCGGGTAACACAGA3' }\end{array}$ \\
\hline BDNF & $\begin{array}{c}\text { Forward 5' ATAATGTCTGACCCCAGTGCC3' } \\
\text { Reverse 5' CTGAGGGAACCCGGTCTCAT3' }\end{array}$ \\
\hline p38 MAPK & $\begin{array}{l}\text { Forward 5' } \text { AGGGCGATGTGACGTTT3' }^{\prime} \\
\text { Reverse 5' CTGGCAGGGTGAAGTTGG3' }\end{array}$ \\
\hline NF- $к B$ & $\begin{array}{c}\text { Forward 5' CATGAAGAGAAGACACTGACCATGGAAA3' } \\
\text { Reverse 5' TGGATAGAGGCTAAGTGTAGACACG3' }\end{array}$ \\
\hline Caspase-3 & $\begin{array}{c}\text { Forward 5' } \text { GTGGAACTGACGATGATATGGC3' }^{\prime} \\
\text { Reverse 5' CGCAAAGTGACTGGATGAACC3' }\end{array}$ \\
\hline$\beta$-actin & $\begin{array}{c}\text { Forward 5' } \\
\text { Reverse 5' CTGCTTGGGGATTGGTGGCTCTA3' } \\
5^{\prime} \text { CTATCCACATCTG3' }\end{array}$ \\
\hline
\end{tabular}

\subsection{Histological studies of brain tissue}

Brains were kept in $10 \%$ neutral formalin. The brain samples were preserved in paraffin blocks, 4micron thickness sections were prepared, collected on glass slides and deparaffinized followed by staining with haematoxylin and eosin for examination using light microscopy. ${ }^{39}$

\subsection{Statistics}

Mean \pm standard error (S.E) was used for data expression. One way analysis of variance (ANOVA) was used to assess variance between groups.
Subsequent multiple comparison between the different groups were done by Duncan's comparisons test. Statistical package for social sciences16 (SPSS) software was used for Statistics. GraphPad Prism software was used for graph construction. Significances was considered where $p$ $<0.05$.

\section{RESULTS}

\subsection{General observations}

AMB-FUBINACA resulted in substantial depressant effects in all rats during the first $10 \mathrm{~min}$, and maximal depression occurred between 10-40 min and continued up to 3 to $6 \mathrm{~h}$ with the highest tested dose $(4 \mathrm{mg} / \mathrm{kg})$. Meanwhile tremors 
happened 30 minutes after drug injection especially with 3 and $4 \mathrm{mg} / \mathrm{kg}$ examined doses. Then rats became hyperactive and aggressive.

\subsection{Effect of AMB-FUBINACA on S100B, TNF- $\alpha$ and IL-6 serum levels:}

Table 2 reveals that, administration of three different doses of AMB-FUBINACA (1, 3 and $4 \mathrm{mg} / \mathrm{kg}$ ) for 6 consecutive days induced significant increases $(\mathrm{p}<0.5)$ of S-100B, TNF- $\alpha$ and interlukine-6 (IL-6) in relation to the control group. Recorded data also reveal that the undue effect of AMB-FUBINACA on the examined serum parameters significantly increases with increasing the examined dose

\subsection{AMB-FUBINACA disturbs the Redox status of the brain}

The administration of AMB-FUBINACA in three different doses induced a significant increase in lipid per oxidative end product (MDA). This escalation in brain malondialdehyde level is in concomitant with a significant reduction in GSH content compared with the control group (Table 3). The obtained data also declared that the disturbance in the redox status of the brain to a great extent depended on the dose of AMB-FUBINACA.

Table 2. Serum levels of S100B, TNF- $\alpha$ and IL-6 in normal rats and under the influence AMB-FUBINACA administration in three doses

\begin{tabular}{cccc}
\hline $\begin{array}{c}\text { Parameters } \\
\text { Groups }\end{array}$ & $\begin{array}{c}\text { S100 } \\
(\mathbf{n g} / \mathbf{m l})\end{array}$ & $\begin{array}{c}\text { TNF- } \boldsymbol{\alpha} \\
(\mathbf{p g} / \mathbf{m l})\end{array}$ & $\begin{array}{c}\text { IL-6 } \\
(\mathbf{p g} / \mathbf{m l})\end{array}$ \\
\hline Control & $1.82 \pm 0.15^{\mathrm{a}}$ & $15.98 \pm 1.16^{\mathrm{a}}$ & $35.37 \pm 1.69^{\mathrm{a}}$ \\
\hline Group 1 & $4.43 \pm 0.34^{\mathrm{b}}$ & $62.73 \pm 4.36^{\mathrm{b}}$ & $104.0 \pm 2.65^{\mathrm{b}}$ \\
\hline Group 2 & $7.93 \pm 0.16^{\mathrm{c}}$ & $94.59 \pm 2.40^{\mathrm{c}}$ & $121.33 \pm 2.34^{\mathrm{c}}$ \\
\hline Group 3 & $13.37 \pm 0.90^{\mathrm{d}}$ & $118.86 \pm 3.97^{\mathrm{d}}$ & $147.37 \pm 5.84^{\mathrm{d}}$ \\
\hline
\end{tabular}

Data are expressed as mean values \pm SE ( $n=8$ rats for each group). In the same column, values with different superscript letters are significantly different $(\mathrm{p}<0.05)$.

Table 3. Effect of three different doses of AMB-FUBINACA on lipid per-oxidative index (MDA) and reduced GSH in brain of rats

\begin{tabular}{ccc}
\hline $\begin{array}{c}\text { Parameters } \\
\text { Groups }\end{array}$ & $\begin{array}{c}\text { MDA } \\
(\mathbf{n M} / \mathbf{m g} \text { protein })\end{array}$ & $\begin{array}{c}\text { GSH } \\
(\mathbf{m M} / \mathbf{m g} \text { protein })\end{array}$ \\
\hline Control & $18.07 \pm 1.66^{\mathrm{a}}$ & $97.97 \pm 5.10^{\mathrm{d}}$ \\
\hline Group 1 & $63.69 \pm 3.86^{\mathrm{b}}$ & $56.07 \pm 1.76^{\mathrm{c}}$ \\
\hline Group 2 & $85.19 \pm 4.03^{\mathrm{c}}$ & $36.47 \pm 1.12^{\mathrm{b}}$ \\
\hline Group 3 & $121.31 \pm 2.53^{\mathrm{d}}$ & $26.41 \pm 1.34^{\mathrm{a}}$ \\
\hline
\end{tabular}

Data are expressed as mean \pm S.E. ( $n=8$ rats). In the same column, values with different superscript letters are significantly different $(\mathrm{P}<0.05)$.

\subsection{Effect of AMB-FUBINACA on mRNA expression levels of $\mathrm{NF} \kappa \mathrm{B}, \mathrm{MAPK}$, Caspase-3, CBR 1, CB2R and BDNF}

The administration of AMB-FUBINACA in three different doses induced a significant increase the expression levels of mRNA expression of NF$\kappa \mathrm{B}(\mathrm{A})$, MAPK P38(B) and Caspase-3(C) in association with a significant decrease in the mRNA expression of CB1 R (A), CB2R (B) and BDNF (C) in the brain tissue comparing to the control group (Fig. 1, 2). The obtained data also demonstrate that, as the examined dose increases the obtained disturbance in the examined mRNA expression levels were augmented.
3.5 The histological changes in brain tissue under the influence of different doses of AMBFUBINACA

The histological examination of control group shows normal cerebral cortex and hippocampus (Fig. 3A, B), meanwhile the administration of $1 \mathrm{mg}$ / $\mathrm{kg}$ body weight of AMB-FUBINACA (Group 1) caused mild pathological alteration where hippocampus and choroid plexus normally appeared, however focal inflammatory aggregates in cerebral cortex could be observed (Fig. 4A, B and C ), while the administration of $3 \mathrm{mg} / \mathrm{kg}$ body weight of AMB-FUBINACA (Group 2) showing focal area of pyknotic cells in hippocampus (Fig. 5A), with sever hemorrhage (Fig. 5B), and inflammatory cell aggregates in ventricle (Fig. 5C), and the microscopical examination of group 3 
revealed that, administration of $4 \mathrm{mg} / \mathrm{kg}$ induced a decrease in cellularity and apoptotic cells in hippocampus (Fig. 6A) dilated congested blood vessel with perivascular inflammation and hemorrhage in ventricle were noticed (Fig. 6B, C)
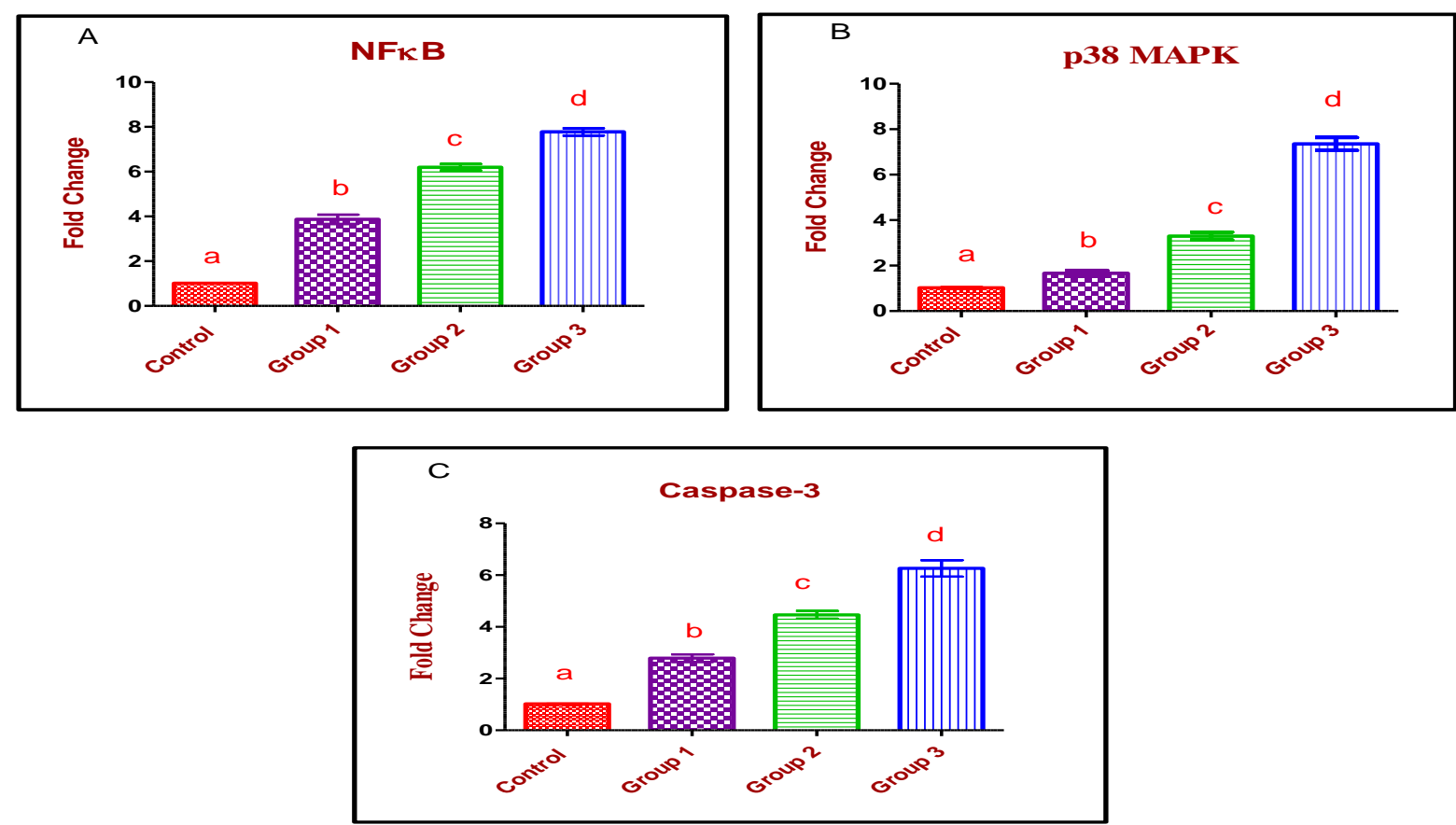

Figure 1. The up-regulation of mRNA expression levels of mRNA expression level of NF-Kb (A), MAPK (B)and Caspase3 (C) in brain tissue under the influence of three doses of AMB-FUBINACA. The steady state levels of mRNA in the brain were analyzed by RT-PCR assay. $\beta$-actin was used as an invariant internal control for calculating mRNA fold changes. Data are expressed as mean values \pm SE ( $n=8$ rats). Mean values with different superscript letters are significantly different $(\mathrm{p}<0.05)$
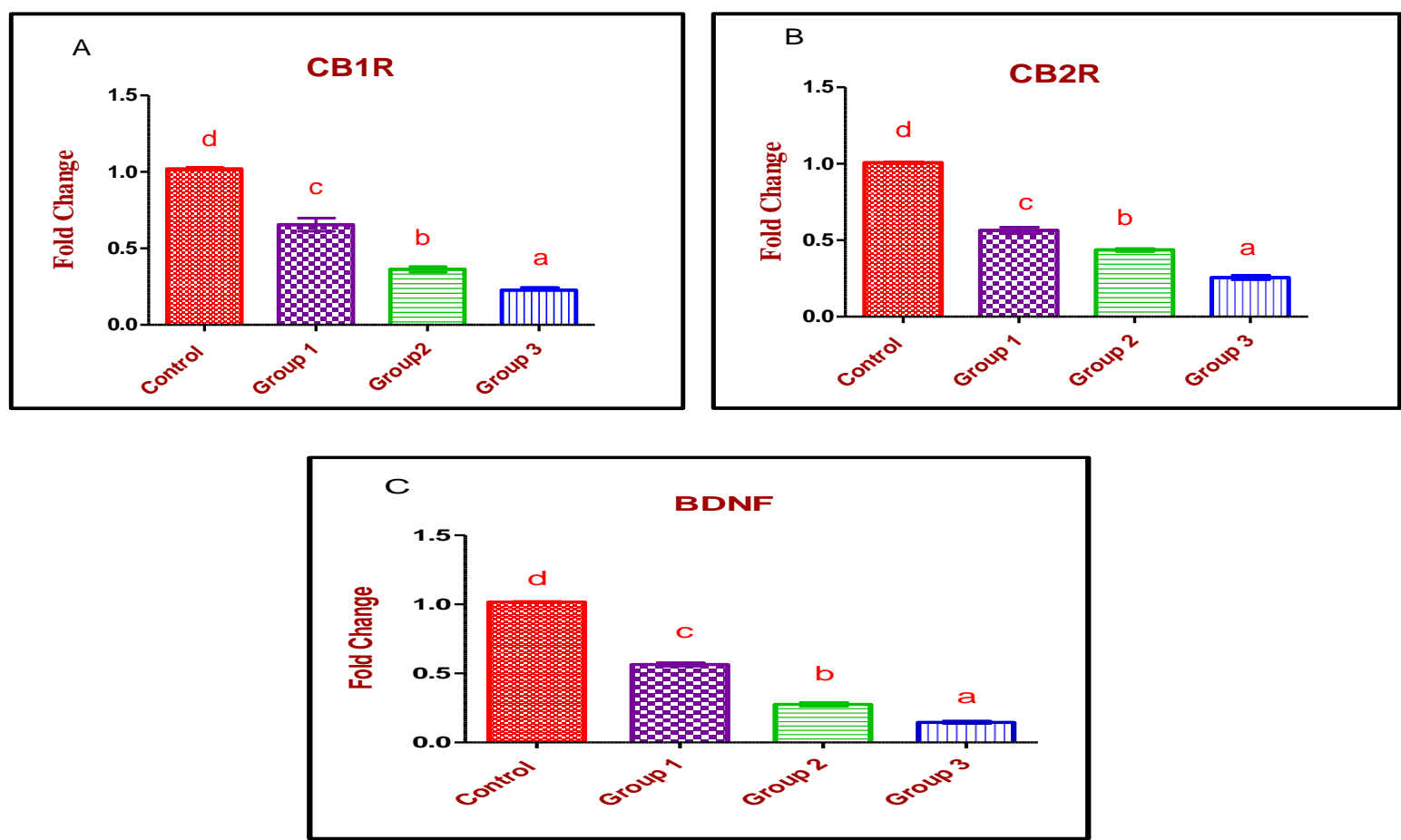

Figure 2. The down- regulation of mRNA expression levels of CB1R (A), CB2R (B)and BDNF (C) in brain tissue under the influence of three doses of AMB-FUBINACA. The steady state levels of mRNA in the brain were analyzed by RT-PCR assay. $\beta$-actin was used as an invariant internal control for calculating mRNA fold changes. Data are expressed as mean values $\pm \mathrm{SE}$ ( $\mathrm{n}=8$ rats). Mean values with different superscript letters are significantly different $(\mathrm{p}<0.05)$ 

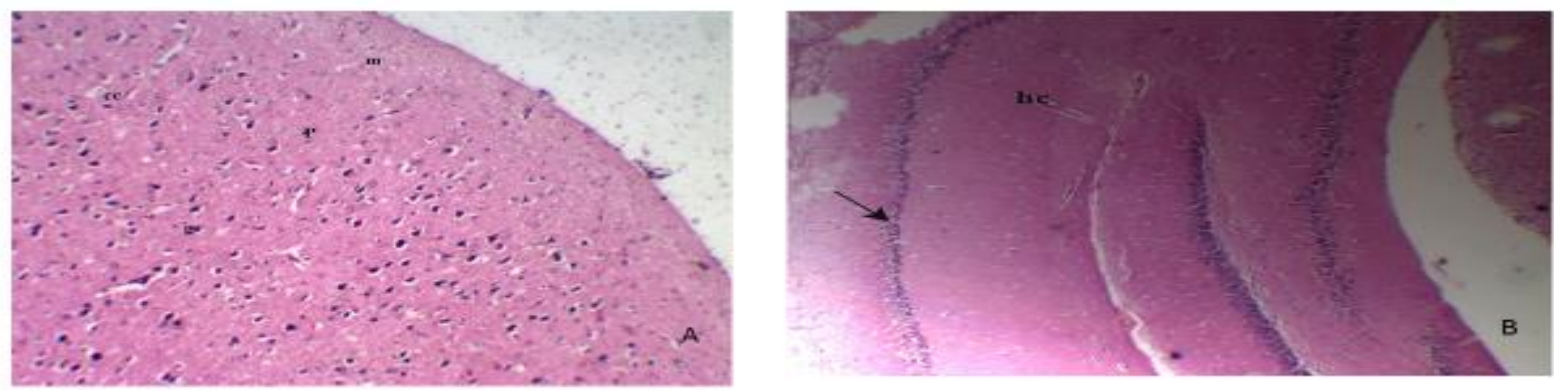

Figure 3. Photomicrograph of brain tissue from control group (A)showing normal cerebral cortex (cc), molecular layer (m), pyramidal layer (p), granular layer (g) (X: 40) and (B) showing normal hippocampus (hc), pyramidal layer (arrow) (X: 100)
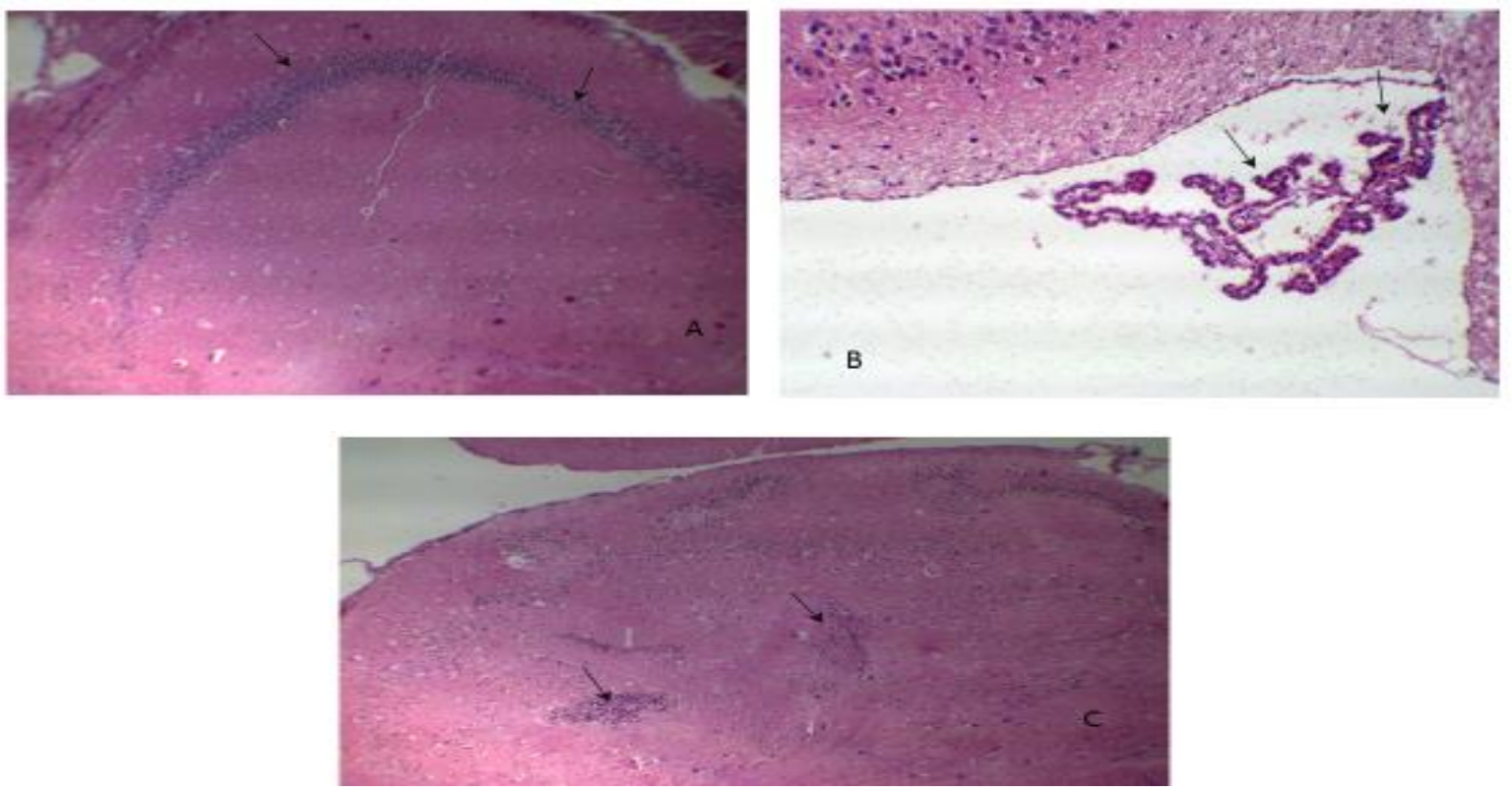

Figure 4. Photomicrograph of brain tissue from group 1: (A) showing normal hippocampus (arrow) (X: 100); (B) showing normal choridate plexus (arrow) (X: 200) and (c) focal inflammatory aggregates in cerebral cortex (arrow) (X: 100)

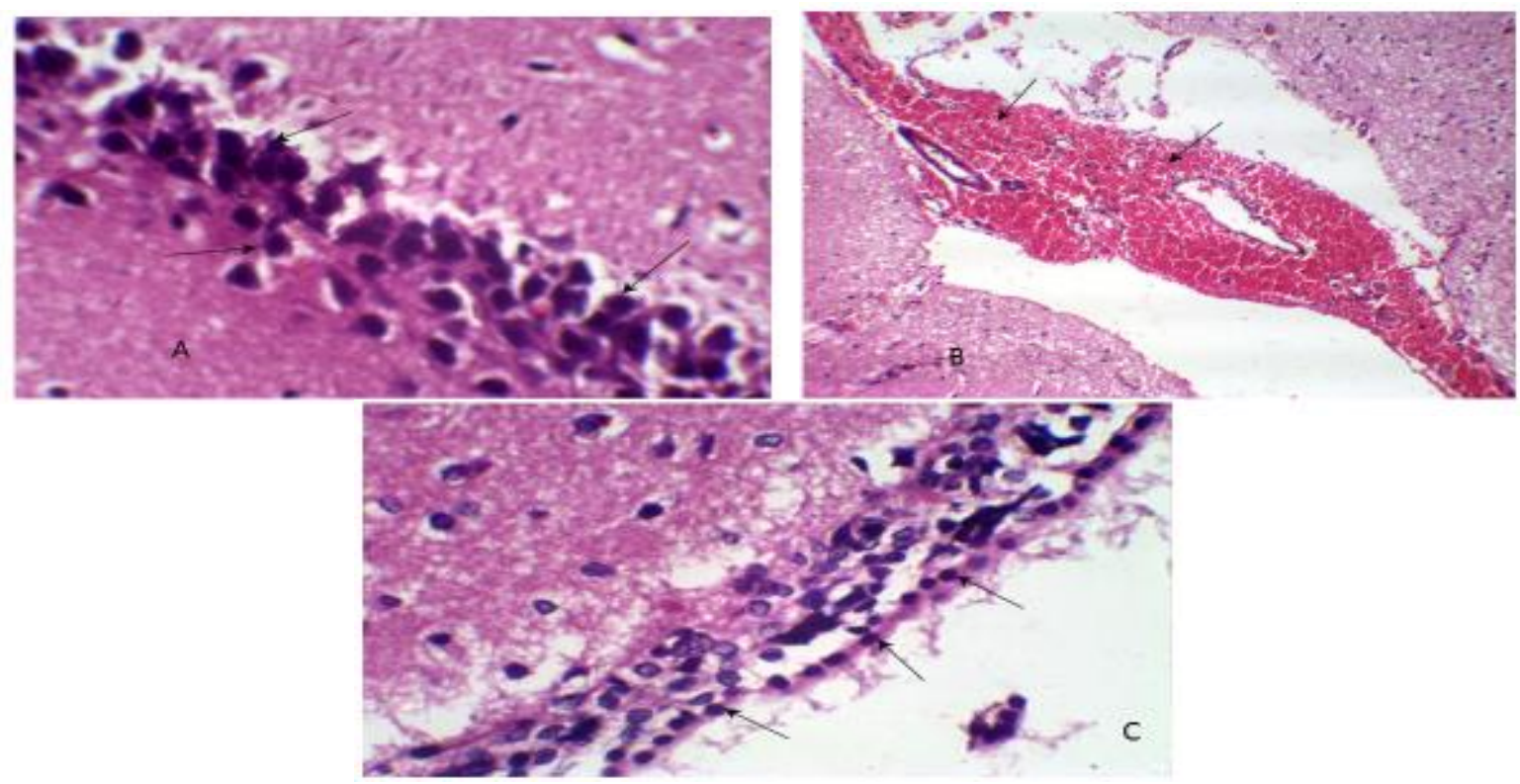

Figure 5. Photomicrograph of brain tissue from group (2) (A) showing hippocampus with pyknotic cells (arrow) (X: 400) (B) showing hemorrhage in ventricle (arrow) (X: 200) and (C) showing inflammatory cells in ventricle (arrow) (X: 400) 

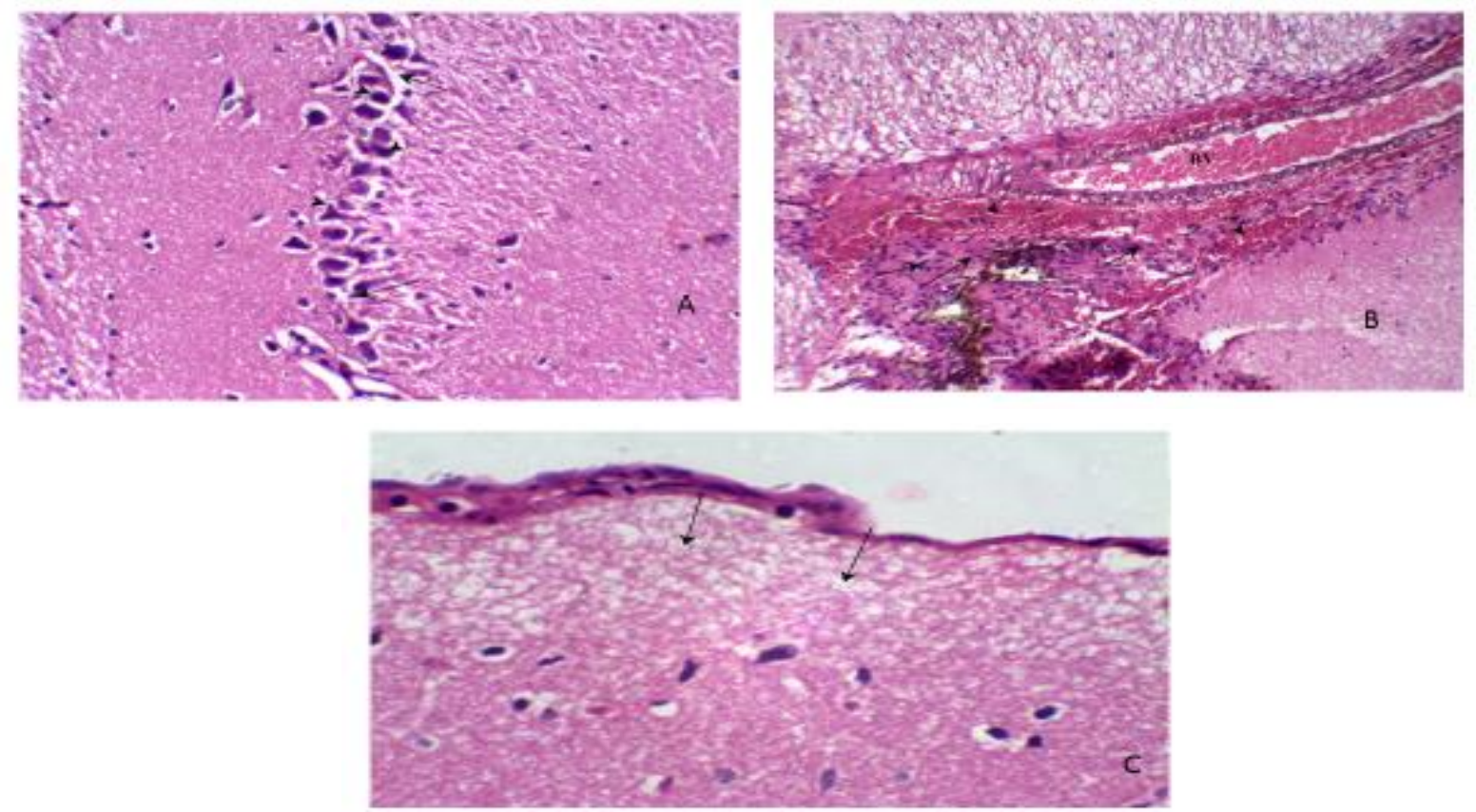

Figure 6. Photomicrograph of brain tissue from group (3) (A)showing hippocampus with less in cellularity (arrow), apoptotic cells (arrow head); (B)showing congested, dilated blood vessel (BV), perivascular inflammation (arrow), hemorrhage (arrow head) and (C) showing mild vacuolation in neuropil (arrow) (X: 400)

\section{DISCUSSION}

In the present study, AMB-FUBINACA injection with the three examined doses resulted in a significant elevations in lipid peroxidation process as manifested by the recorded increase in MDA levels in brain tissue. This increment is dose dependent and accompanied with a significant reduction in the brain content of GSH. This disturbance in the redox status of the brain proves the production of free radicals and the generation of oxidative stress which has been involved as a mechanism underlying the neuronal oxidative injury. ${ }^{10}$ Moreover, MDA, is a neuronal toxin which could affect protin. ${ }^{40}$ Therefore, ROS have indispensable role in the pathology of neurological disease. ${ }^{\mathbf{1 1}}$ This finding agrees with several studies that confirm the role of ROS in the induction of toxic effects among cannabinoid users, ${ }^{41,12,14}$ in addition ROS production is a mechanism involved in stroke. ${ }^{42}$ Additionally, free radicals activate neuron inflammation by up-regulating the production of cytokines and chemokines, which could cause loss of synapses, neuronal apoptosis, and so cognitive dysfunction. ${ }^{\mathbf{4 3},}{ }^{44}$ ROS are also substantially involved in numerous behavioral alteration, including depression, memory impairments and anxiety. ${ }^{\mathbf{1 5}}$

Activation of microglial cells within CNS by harmful stimuli is the first step inducing neuron inflammation. ${ }^{45}$ As activated microglia (MG) release cytotoxic factors such as interlukin-1 (IL-1), IL-6, TNF- $\alpha$, adhesion molecules and ROS, ${ }^{46-48}$ in the CNS. These factors could result in neuronal cell death and lead to more MG activation with more exacerbation of neuronal injury. ${ }^{49}$ In the present study the IL-6 and TNF- $\alpha$ levels were increased with increasing the dose. The obtained data of the current study are in the same line with that obtained by Oztas et al., ${ }^{50}$ who reported the impact of the synthetic cannabinoid AKB48 in the induction of a dose dependent significant increment in TNF- $\alpha$ and IL-6, revealing the neurotoxicity of AKB48 which is one of the third-generation psychoactive synthetic cannabinoid (Apinca). The obtained data in the current study also confirmed the finding of Guler et al. ${ }^{51}$ who recorded a significant elevation of IL-6, and TNF- $\alpha$ serum levels in synthetic cannabinoids users. So the present study proved the impact of inflammatory mediators among cannabinoid users.

Nuclear factor kappa B (NF- $\kappa \mathrm{B})$ has a pivotal function in expression of inflammatory mediators. It affects transcriptional activity via binding with certain sequences in genes that are responsible for immunological and inflammatory processes ${ }^{52}$ In the present study, the mRNA expression level of NF- $\kappa \mathrm{B}$ was significantly increased in rats treated with the examined drug. This finding reinforces the role of AMB- FUBINACA in the induction of brain injury. Moreover, the obtained increase in the circulatory TNF- $\alpha$ and IL-6 is in concomitant with their 
mediator $\mathrm{NF}-\kappa \mathrm{B}$ expression that occurred and propagated in the injured brain as the dose of the examined drug increased, which support the positive correlation between TNF- $\alpha$, IL- 6 and NF$\kappa \mathrm{B}$. This finding proved the impact of SCs in the generation and development of brain injury.

It has been reported that, p38 MAPK and NF$\kappa \mathrm{B}$ pathways in brain participate in the production of cytokines and other harmful molecules. ${ }^{53-55}$ In addition Roy et al. ${ }^{56}$ found that p38 MAPK has a significant effect in the process of neuronal cell death after ischemia in animals with stroke. In the current study the I.P. administration of AMBFUBINACA induced a dose dependent significant elevation in the mRNA expression levels of p83 MAPK. This finding clearly declares the contribution of the synthetic cannabinoids in the induction of neuronal damage and confirmed the findings of researchers who reported that, ${ }^{53-55}$ in harmony with the obtained results $\mathrm{Zhu}$ et al. ${ }^{57}$ reported that, MAPK and NF- $\kappa \mathrm{B}$ signaling pathway mediates microglial inflammatory response in the induction of brain injury. Additionally, MAPK/NF$\kappa \mathrm{B}$ pathway activation also generates ROS which could also participate in neuronal damage as recorded by Zhang et al. ${ }^{47}$

In the current study the obtained increment in serum S100 is a dose dependent and is considered a biomarker of several brain diseases such as brain tumors, neuron inflammation, neuron degeneration and acute brain injury. ${ }^{27}$ Liu et al., ${ }^{58}$ reported neurotoxicity as a result of S100B overexpression. Also, studies have revealed that serum level of S100B could be a dependable biomarker in prediction and prognosis of cerebral infraction ${ }^{59}$, ${ }^{60}$.Therefore, S100B has a vital role as a biomarker for brain damage, which could result in psychiatric disorders, substance abuse as well as structural brain damage 61,62

Brain derived neurotrophic factor (BDNF) has a role in the pathology of neurodegenerative disorders. ${ }^{63}$ In the current work administration of the examined drug at the three dosage levels caused a significant decline in BDNF mRNA expression. Oxidative stress may be increased in conditions with decreased BDNF. ${ }^{64,65}$ This fact is emphasized in the current study through the negative correlation between the increment in lipid per-oxidative index end products MDA and the obtained decline in BDNF mRNA expression levels. In addition the recorded results of this study confirmed the role of inflammatory mediators in the down- regulation of BDNF among synthetic cannabinoids users . ${ }^{63,66,67}$
It has been shown that, caspase-3 is a wellrecognized hallmark of neuronal cell death in many CNS disorders. ${ }^{68-70}$ Assessement of caspase-3 mRNA expression level in the current study was performed to ascertain apoptosis in brain. The recorded increase in caspase- 3 mRNA expression provides evidence about the contribution of synthetic cannabinoid abuse in the activation of caspase- 3 to promote cellular apoptosis in brain in a dose dependent manner. This finding is in harmony with that of Almada et al., ${ }^{71}$ the authors demonstrated the impact of JWH-018, JWH-122, UR-144 SCs and the THC in increasing the production of ROS with the induction of apoptotic pathways through the activation of caspases-9, 7 and 3.

It has been reported that SCs often act by modulating the action of endo-cannabinoids on CB1 $50,72,73$ and CB2 receptors ${ }^{74,75}$ to exert their effects as a result of synthetic cannabinoids administration. Oztas et al., ${ }^{50}$ reported that cannabinoid B1receptor expression was well markedly increased under the influence of synthetic cannabinoid AKB48 administration in a dose dependent manner, meanwhile cannabinoid CB2 receptor was not expressed in SH-SY5Y cells. On the other hand our data recorded a significant decline in the mRNA expression of the both examined receptors under the influence of AMB-FUBINACA administration at the three examined doses. In addition the magnitude of this decrement increased as the dose of the examined drug increase. These contradictory findings recorded in the current study may be pointed out that the synthetic cannabinoid, AMBFUBINACA used in the current study with doses 1, 3 and $4 \mathrm{mg} / \mathrm{kg}$ for six days which mimic and exceed the sub-chronic (four days) administration that reported by Dalton et al. ${ }^{76}$ The authors revealed a pronounced decline in $\mathrm{CB} 1$ receptor density in rat brain following acute, 4 days (sub chronic) and 14 days (chronic) administration of HU210, which is a potent SC, that totally agree with the obtained results of the current study. So in the present study the obtained down- regulation in the $\mathrm{CB}$ receptors may reflect the effect of dose concentration and the duration of the experiment in inducing receptors down-regulation through drug tolerance, since receptors down-regulation together with the retention of G-protein activity considered a mechanism for tolerance, whereas cannabinoids tolerance was recorded after chronic use. ${ }^{77}$

Several molecular mechanisms mediating the down regulation of $\mathrm{CB} 1$ receptors have been proposed. Sim-Selley et al., ${ }^{78}$ reported that CB1 receptors down-regulation was achieved through the 
receptor protein rather than gene expression. Moreover Villares ${ }^{79}$ demonstrated that the CB1R cDNA expression in brain decline with long term cannabis abuse causing CB1R down-regulation, and thus decline in the binding capacity which might illustrate that the primary action of synthetic cannabinoid could be on the expression of CB1 receptor gene rather than the protein. Using HEK293 cells that contain neurons express CB1R by Martini et al., ${ }^{80}$ showed that treatment with cannabinoid agonist (WIN55, 212-2) resulted in CB1R endocytosis and degradation and that the GASP1 has a major role in this process that could explain a molecular mechanism for the decline of receptor density. Nguyen et al.; Schmid et al.; Walsh and Andersen ${ }^{59,} 81,82$ demonstrated the function of GRK in recruitments of both $\beta$-arrestin 1 and 2 to receptors that leads to desensitization and internalization of CB1R.

In the current study $\mathrm{CB} 2$ receptor mRNA was expressed in control rats confirmed its prevalence in the brain tissue ${ }^{83,84}$ and down regulated in AMBFUBINACA challenged rats. This finding may declare that $\mathrm{CB} 2$ receptor plays a significant role in immunological function rather than the other neuronal function in neuronal processes. The increased NF- $\kappa \mathrm{B}$ expression and the increased levels of serum IL- 6 and TNF- $\alpha$ play a key role in inducement and continuation of inflammation in macrophage, ${ }^{85}$ therefore, the down regulation of CB2 R in this study can be considered as important signal in the pathogenesis of neuronal disorders which can be assured by the increased expression of $\mathrm{NF}-\kappa \mathrm{B}$ that is mediated by successive increase of MAPK p38. Accordingly, we can speculate that CB1 and CB2 receptors work independently to regulate $\mathrm{CNS}$ physiological activities. The down regulation of $C B 1 R$ and $C B 2 R$ that obtained in the current study should be taken into consideration by future studies investigating $\beta$-arrestin recruitment to synthetic cannabinoids receptors to avoid misplaced conclusions.

\section{Conclusion}

In the light of all findings, the current study concluded that: AMB-FUBINACA was found to have a functional and structural deleterious CNS effects with sub chronic exposure in adult male albino rats. The induced brain injury and seizures that accompanied with the synthetic cannabinoids abuse might be mediated through the generation of oxidative stress, activating inflammatory cellular signaling mechanism and neural cell death via apoptosis.
Aknowledgment: The authors express their gratitude to all who participate with their assistance in the completion of all biochemical measurements.

Ethical Statement: The protocol approval number given by Faculty of Pharmacy Al-Azhar University Research Ethics Committee is (185/2018).

\section{Conflicts of Interest: No.}

Funding statement: This research received no external funding.

Authors' Contribution: All authors participated in conducting the experiment, analysis of samples and writing the manuscript.

\section{References}

1. EMCDDA (European Monitoring Centre for Drugs and Drug Addiction). European Drug Report 2020: Trends and Developments; European Union Publications Office: Luxembourg, 2020.

2. Adamowicz PM and Maslanka M. Fatal Intoxication with New Synthetic Cannabinoids AMB-FUBINACA and EMB-FUBINACA. Clin. Toxicol. 2019;57, 1103-1108.

3. Adams AJ, Banister SD, Irizarry L, Trecki J, Schwartz M, Gerona R. "Zombie" Outbreak caused by the Synthetic Cannabinoid AMBFUBINACA in New York. N. Engl. J. Med. 2017; 376, 235-242.

4. Lam RT, Leung S, Chong Y, Tsui M, Mak T. Supraventricular Tachycardia and Acute Confusion Following Ingestion of E-cigarette Fluid Containing AB-FUBINACA and ADBFUBINACA: A Case Report with Quantitative Analysis of Serum Drug Concentrations. Clin. Toxicol. 2017; 55, 662-667.

5. Shanks KG, Clark W, Behonick G. Death Associated with the Use of the Synthetic Cannabinoid ADB-FUBINACA. J. Anal. Toxicol. 2016;236-239.

6. EMCDDA (European Monitoring Centre for Drugs and Drug Addiction). European Drug Report 2018: Trends and Developments; European Union Publications Office: Luxembourg, 2018.

7. EMCDDA (European Monitoring Centre for Drugs and Drug Addiction). Fentanils and 
Synthetic Cannabinoids: Driving Greater Complexity into the Drug Situation; An update from the EU Early Warning System; Publications Office of the European Union: Luxembourg, 2018.

8. Wolff V, Schlagowski AI, Rouyer O, Charles AL, Singh F, Auger C, et al.Tetrahydrocannabinol induces brain mitochondrial respiratory chain dysfunction and increases oxidative stress: a potential mechanism involved in cannabis-related stroke. BioMed Res Int. 2015;323706.

9. Halliwell B and Gutteridge E. Free radicals in biology \& medicine, 5th ed. USA: Oxford University Press, 2015.

10. Kruk-Slomka M, Boguszewska-Czubara A, Slomka T, Budzynska B, Biala G. Correlations between the Memory-Related Behavior and the Level of Oxidative Stress Biomarkers in the Mice Brain, Provoked by an Acute Administration of CB Receptor Ligands. Neural Plast. 2016; 9815092.

11. Patel M. Targeting oxidative stress in central nervous system disorders. Trends Pharmacol. Sci. 2016; 37, 768-778.

12. Wolff V. and Jouanjus E.. Strokes are possible complications of cannabinoids use. Epilepsy Behav 2017; 70: 355-363.

13. Hirapara K. and Aggarwal R. Synthetic cannabis use and stroke: a rising risk? Int $\mathrm{J}$ Stroke 2016; 11: NP78-NP78.

14. Singh A, Saluja S, Kumar A, Agrawal S, Thind M, Nanda S. et al. Cardiovascular complications of marijuana and related substances: a review. Cardiol Ther 2018; 7(1): 45-59.

15. Black CN, Bot M, Scheffer PG, Penninx BW. Oxidative stress in major depressive and anxiety disorders, and the association with antidepressant use; results from a large adult cohort. Psychol. Med. (Paris) 2017; 47, 936948.

16. Prakash $\mathrm{S}$ and Smith A. TNF- $\alpha$. (Tumor Necrosis Factor- $\alpha$ ) a paradox in thrombosis. Arterioscler Thromb Vasc Biol. 2018; 38:25422543.
17. Pawluk H, Woźniak A, Grześk G, Kołodziejska R, Kozakiewicz M, Kopkowska E, Grzechowiak E, Kozera G. The Role of Selected Pro-Inflammatory Cytokines in Pathogenesis of Ischemic Stroke. Clin Interv Aging. 2020 Mar 23; 15:469-484.

18. Okada F. Inflammation-related carcinogenesis: current findings in epidemiological trends, causes and mechanisms. Yonago Acta Med. 2014; 57(2):65-72.

19. Benedict CA. What Is Nuclear Factor Kappa $\mathrm{B}$ (NF-kB) Doing in and to the Mitochondrion. Frontiers in Cell and Developmental Biology. 2019August; Volume 7, Article 154

20. El-Shamarka ME, Sayed RH, Assaf N, Zeidan HM, Hashish AF. Combined neurotoxic effects of cannabis and nandrolone decanoate in adolescent male rats. Neurotoxicology. 2020; J76:114-125.

21. Matsumoto J, Dohgu S, Takata F, et al. TNF$\alpha$-sensitive brain pericytes activate microglia by releasing IL-6 through cooperation between IjBNFjB and JAK-STAT3 pathways. Brain Res. 2018; 1692:34-44.

22. Gräb J, Rybniker J. The Expanding Role of p38 Mitogen-Activated Protein Kinase in Programmed Host Cell Death. Microbiology Insights. 2019 January.

23. Keshet $\mathrm{Y}$ and Seger R. The MAP kinase signaling cascades: a system of hundreds of components regulates a diverse array of physiological functions. Methods Mol Biol. 2010; 661:3-38.

24. de Vasconcelos NM,Opdenbosch NV, Gorp HV,Martı'n-Pe'rez R, Zecchin A, Vandenabeele P, Lamkanfi M. An Apoptotic Caspase Network Safeguards Cell Death Induction in Pyroptotic Macrophages Cell Reports, Volume 32, Issue 4, 2020;107959,ISSN 2211-1247.

25. Glushakova OY, Glushakov AA, Wijesinghe DS, Valadka AB, Hayes RL, Glushakov AV. Prospective clinical biomarkers of caspasemediated apoptosis associated with neuronal and neurovascular damage following stroke and other severe brain injuries: Implications for chronic neurodegeneration. Brain Circ. 2017; 3(2):87-108. 
26. Lima Giacobbo B, Doorduin J, Klein HC, Dierckx RAJO, Bromberg E, de Vries EFJ. Brain-Derived Neurotrophic Factor in Brain Disorders: Focus on Neuroinflammation. Mol Neurobiol. 2019; 56(5):3295-3312.

27. Michetti F, Corvino V, Geloso MC, Lattanzi W, Bernardini C, Serpero L, et al. The S100B protein in biological fluids: more than a lifelong biomarker of brain distress. J Neurochem 2012; 120:644-59.

28. DEA (Drug Enforcement Administration). Annual Emerging Threat Report. 2017.

29. World Drug Report. SIRIUS - United Nations Publication. 2018.

30. Freund S.A., Banning A.S. Synthetic Cannabinoids: A Review of the Clinical Implications of a New Drug of Choice. JAAPA 2017; 30, 1-4.

31. Tai S. and Fantegrossi W.E. Pharmacological and Toxicological Effects of Synthetic Cannabinoids and their Metabolites. Curr. Top. Behav. Neurosci. 2016; 32, 249-262.

32. Gamage TF, Farquhar CE, Lefever TW, Marusich JA, Kevin RC, McGregor IS et al., Molecular and Behavioral Pharmacological Characterization of Abused Synthetic Cannabinoids MMB-and MDMB-FUBINACA, MN-18, NNEI, CUMYL-PICA, and 5-FluoroCUMYL-PICA. J. Pharm. Exp. 2018;,365, 437446.

33. Noble C, Cannaert A, Linnet K., Stove CP. Application of an Activity-based Receptor Bioassay to Investigate the In Vitro Activity of Selected Indole-and Indazole-3-carboxamidebased Synthetic Cannabinoids at CB1 and CB2 Receptors. Drug Test. Anal. 2019;, 11, 501-511.

34. Banister SD, Moir M, Stuart J, Kevin RC, Wood KE, Longworth M. et al., Pharmacology of Indole and Indazole Synthetic Cannabinoid Designer Drugs AB-FUBINACA, ADBFUBINACA, AB-PINACA, ADB-PINACA, 5F-AB-PINACA, 5F-ADB-PINACA, ADBICA, and 5F-ADBICA. ACS Chem. Neurosci. 2015;, 6, 1546-1559.

35. Lobato-Freitas C., Brito-da-Costa A.M., Dinis-Oliveira R.J., Carmo H., Carvalho F., Silva J.P., Dias-da-Silva D. Overview of Synthetic Cannabinoids ADB-FUBINACA and
AMB-FUBINACA: Clinical, Analytical, and Forensic Implications. Pharmaceuticals 2021;14, 186.

36. Gatch MB and Forster MJ Cannabinoid-like effects of five novel carboxamide synthetic cannabinoids Neurotoxicology 2019; 70. 72-79

37. Canazza I, Ossato A, Vincenzi F, Gregori A, Di Rosa F, Nigro $F$ et al .Pharmacotoxicological effects of the novel thirdgeneration fluorinate synthetic cannabinoids, 5F-ADBINACA, AB-FUBINACA, and STS135 in mice. In vitro and in vivo studies. Hum Psychopharmacol. 2017 May;32(3).

38. Livak KJ, Schmittgen TD. Analysis of relative gene expression data using Real-Time Quantitative PCR and the 2 (-Delta Delta C (T)) Method. METHODS 2001; 25 (4): 402-408.

39. Bancroft JD, Stevens A and Dawswon MP. Theory and practice of histological techniques. 4th ed. Churchill Livingstone, Edinbergh ,London and New York P. 1996; 273:292 .

40. Agostinho P, Cunha R A and Oliveira C. "Neuroinflammation, oxidative stress and the pathogenesis of Alzheimer's disease," Current Pharmaceutical Design, vol. 16, no. 25, 2010; pp. 2766-2778.

41. Hirapara K and Aggarwal R. Synthetic cannabis use and stroke: a rising risk? Int $\mathbf{J}$ Stroke 2016; 11: NP78-NP78.

42. Chen H, Yoshioka H, Kim GS, et al. Oxidative stress in ischemic brain damage: mechanisms of cell death and potential molecular targets for neuroprotection. Antioxid Redox Signal 2011; 14: 1505-1517.

43. Valko M, Leibfritz D, Moncol J, Cronin MT, Mazur M, and Telser J, "Free radicals and antioxidants in normal physiological functions and human disease,'The International Journal of Biochemistry \& Cell Biology, 2007; vol. 39, no. 1,pp. 44-84.

44. Zhou WW, Lu S, Su YJ, Xue D, Shaowei Wang XY, Zhang $\mathrm{H}$ et al., Decreasing oxidative stress and neuroinflammation with a multifunctional peptide rescues memory deficits in mice with Alzheimer disease. Free Radical Biology and Medicine 2014; vol. 74, pp. 50-63. 
45. Hanisch UK, Kettenmann H Microglia. active sensor and versatile effector cells in the normal and pathologic brain. Nat Neurosci 2007; 10:1387-1394.

46. Jeong JW, Jin CY, Kim GY. et al., "Antiinflammatory effects of cordycepin via suppression of inflammatory mediators in BV2 microglial cells," International Immunopharmacology, 2010; vol. 10, no. 12, pp. $1580-1586$.

47. Zhang L, Wu C, Zhao S. et al., "Demethoxycurcumin, a natural derivative of curcumin attenuates LPS-induced proinflammatory responses through downregulation of intracellular ROS-related MAPK/NF- $\kappa$ B signaling microglia induced by lipopolysaccharide," International Immunopharmacology , 2010; vol. 10, no. 3, pp. 331-338.

48. He GY, Yuan CG, Hao L, Xu Y, Zhang ZX. GBE50 Attenuates Inflammatory Response by Inhibiting the $\mathrm{p} 38 \mathrm{MAPK}$ and NF- $\kappa$ B Pathways in LPS-Stimulated Microglial Cells. Evid Based Complement Alternat Med. 2014; 368598.

49. Block ML, Zecca L, and Hong JS, "Microgliamediated neurotoxicity: uncovering the molecular mechanisms," Nature Reviews Neuroscience 2007; vol. 8, no. 1, pp. 57-69.

50. Oztas E, Abudayyakb M, Celiksoza M, Özhana G. Inflammation and oxidative stress are key mediators in AKB48-induced neurotoxicity in vitro. Toxicology in Vitro 55 2019; 101-107.

51. Guler EM, Bektay MY, Akyildiz AG, Sisman $\mathrm{BH}$, Izzettin FV and Kocyigit A. Investigation of DNA damage, oxidative stress, and inflammation in synthetic cannabinoid users. Human and Experimental Toxicology 2020; Vol. 39(11) 1454-1462.

52. Bai AP, Ouyang Q, Xiao XR, Li SF. Probiotics modulate inflammatory cytokine secretion from inflamed mucosa in active ulcerative colitis. Int J Clin Pract 2006; 60: 284-288.

53. Li Y, Chen G, Zhao J, Nie X, Wan C, Liu J et al. "2,3,7,8-Tetrachlorodibenzo-pdioxin (TCDD) induces microglial nitric oxide production and subsequent rat primary cortical neuron apoptosis through p38/JNKMAPKpathway,” Toxicology , 2013; vol. 312, pp. 132-141.
54. Oh WJ, Jung U, Eom HS, Shin HJ, and Park HR, "Inhibition of lipopolysaccharide-induced proinflammatory responses by Buddleja officinalis extract in BV-2 microglial cells via negative regulation of $\mathrm{NF}-\kappa \mathrm{B}$ and ERK1/2 signaling," Molecules , 2013; vol. 18, no. 8, pp. 9195-9206.

55. Park SY, Jin ML, Kim YH, Kim Y and Lee SJ. "Antiinflammatory effects of aromaticturmerone through blocking of NF- $\kappa \mathrm{B}$, JNK, and p38 MAPK signaling pathways in amyloid $\beta$-stimulated microglia," International Immunopharmacology , 2012; vol. 14, no. 1, pp. 13-20.

56. Roy Choudhury G, Ryou MG, Poteet E, Wen $\mathrm{Y}$, He R, Sun F, et al. Involvement of p38 MAPK in reactive astrogliosis induced by ischemic stroke. Brain Res 2014; 1551:45-58.

57. Zhu X, Wei D, Chen O, Zhang Z, Xue J, Huan $\mathrm{Sg}$, et al. Upregulation of CCL3/MIP-1alpha regulated by MAPKs and NF-kappaB mediates microglial inflammatory response in LPS-induced brain injury. Acta Neurobiol Exp 2016, 76: 304-317

58. Liu CH, Lin YW, Tang NY, Liu HJ, Huang CY, Hsieh CL. Effect of oral administration of Pheretima aspergillum (earthworm) in rats with cerebral infarction induced by middle-cerebral artery occlusion. Afr J Tradit Complement Altern Med 2012; 10: 66-82.

59. Nguyen PT, Schmid CL, Raehal KM, Selley DE, Bohn LM, and Sim-Selley LJ. B-Arrestin2 Regulates Cannabinoid CB1 Receptor Signaling and Adaptation in a Central Nervous System RegionDependent Manner. Biol Psychiatry 2012; 71:714-724 715

60. Zurek J, Fedora M. The usefulness of S100B, NSE, GFAP, NF-H, secretagogin and Hsp70 as a predictive biomarker of outcome in childrenwith traumatic brain injury. Acta Neurochir (Wien) 2012;154: 93-103.

61. Bayazit H, Cicek E, Selek S, Karababa, I.F., Cicek, E., Aksoy, N., 2017. Evaluation of oxidant/ antioxidant status and cytokine levels in patients with cannabis use disorder Clin. Psychopharmacol. Neurosci. 2017; 15 (3), 237.

62. Langeh U and Singh S. Targeting S100B Protein as a Surrogate Biomarker and its Role in Various Neurological Disorders. Current 
Neuropharmacology, Volume 19, Number 2, 2021; pp. 265-277(13).

63. Giacobbo BL, Doorduin J, Klein HC, Dierckx RA, Bromberg E and Vries EF. Brain-Derived Neurotrophic Factor in Brain Disorders: Focus on Neuroinflammation. Molecular Neurobiology 2009;56:3295-3312.

64. Wu A., Ying Z., Gomez-Pinilla F. The interplay between oxidative stress and brainderived neurotrophic factor modulates the outcome of a saturated fat diet on synaptic plasticity and cognition. Eur. J. Neurosci 2004; 19 1699-1707.

65. Kapczinski F, Frey BN, Andreazza AC, Anna MK, Cunha AB, Post RM. Increased oxidative stress as a mechanism for decreased BDNF levels in acute manic episodes. Rev Bras Psiquiatr. 2008.

66. Jiang Y, Wei N, Zhu J, Lu T, Chen Z, Xu G, Liu X. Effects of brain-derived neurotrophic factor on local inflammation in experimental stroke of rat. Mediators Inflamm. 2010; 2010:372423.

67. Shi SS, Shao SH, Yuan BP, Pan F, Li ZL. Acute stress and chronic stress change brainderived neurotrophic factor (BDNF) and tyrosine kinase-coupled receptor (TrkB) expression in both young and aged rat hippocampus. Yonsei Med J. 2010; 51(5):66171.

68. Eldadah, BA., Faden AI. Caspase pathways, neuronal apoptosis, and CNS injury. J. Neurotrauma 2000; 17, 811-829.

69. Glushakova, OY, Johnson D, Hayes RL. Delayed increases in microvascular pathology after experimental traumatic brain injury are associated with prolonged inflammation, bloodbrain barrier disruption, and progressive white matter damage. J. Neurotrauma 2014; 31, 1180 1193.

70. Fang J, Zhu Y, Wang H, Cao B, Fei M, Niu W, Zhou Y, Wang X, Li X and Zhou M .Baicalin Protects Mice Brain From Apoptosis in Traumatic Brain Injury Model Through Activation of Autophagy. Front. Neurosci. 2019; 12:1006.

71. Almada M, Alvesa P, Fonsecaa PM, Carvalhob F, Queirósc CR, Gasparc H et al.
Synthetic cannabinoids JWH-018, JWH-122, UR-144 and the phytocannabinoid THC activate apoptosis in placental cells. Toxicology Letters 319 2020; 129-137.

72. Giacomo VD, Ruehle S, Lutz B, H“aring M , Remmers F: Differential glutamatergic and GABAergic contributions to the tetrad effects of $\Delta$ 9-tetrahydrocannabinol revealed by cell-typespecific reconstitution of the $\mathrm{CB} 1$ receptor. Neuropharmacology 179 ,2020; 108287

73. Tomiyama $\mathrm{K}$ and Funada M. Cytotoxicity of synthetic cannabinoids on primary neuronal cells of the forebrain: the involvement of cannabinoid CB1 receptors and apoptotic cell death. Toxicology and Applied Pharmacology. 2014; vol. 274 (1): 17-23

74. Onaivi ES, Gong HJ, Patel S, Perchuk A, Paul A. Meozzi, PA et al. Discovery of the Presence and Functional Expression of Cannabinoid CB2 Receptors in Brain Ann. N.Y. Acad. Sci. 2006; 1074: 514-536

75. Basavarajappa BS and Subbanna S. Potential Mechanisms Underlying the Deleterious Effects of Synthetic Cannabinoids Found in Spice/K2 Products Brain Sci. 2019;9, 14.

76. Dalton VS, Wang $\mathrm{H}$ and Zavitsanou K. HU210-Induced Downregulation in Cannabinoid CB1 Receptor Binding Strongly Correlates with Body Weight Loss in the Adult Rat. Neurochem Res 2009; 34:1343-1353.

77. Martin BR, Sim-Selley LJ, Selley DE. Signaling pathways involved in the development of cannabinoid tolerance. Trends Pharmacol Sci , 2004; 6:325-330.

78. Sim-Selley, LJ, Schechter NS, Rorrer WK, Dalton GD, Hernandez J, Martin BR et al. Prolonged recovery rate of $\mathrm{CB} 1$ receptor adaptation after cessation of longterm cannabinoid administration. Mol. Pharmacol. 2006; 70, 986-996.

79. Villares J. Chronic use of marijuana decreases cannabinoid receptor binding and mRNA expression in the human brain. Neuroscience 145, 2007; 323-334

80. Martini L, Waldhoer M, Pusch M, Kharazia V, Fong J, Lee JH, Freissmuth $\mathrm{C}$ et al. Whistler. Ligand-induced down-regulation of the cannabinoid 1 receptor is mediated by the G- 
protein-coupled receptor-associated sorting protein GASP1. FASEB J. 2007; 21, 802-811

81. Schmid, CL, Kennedy NM, Ross NC, Lovell KM, Yue Z, Morgenweck J et al.. Bias factor and therapeutic window correlate to predict safer opioid analgesics. Cell 2017;, 171, 1165-1175.

82. Walsh KB and Andersen HK.. Molecular Pharmacology of Synthetic Cannabinoids: Delineating CB1 Receptor-Mediated Cell Signaling. International Journal of Molecular Science.2020; 21, 6115.

83. Onaivi ES, Ishiguro H, Gong JP, Patel S, Meozzi PA, Myers L, et al. Functional expression of brain neuronal CB2 cannabinoid receptors are involved in the effects of drugs of abuse and in depression. Ann N Y Acad Sci 2008; 1139: 434-49.

84. Chen DJ, Gao M, Gao FF, Su QX, Wu J. Brain cannabinoid receptor 2: expression, function and modulation. Acta Pharmacologica Sinica 2017; 38: 312-316.

85. Schulz R. TNF alpha in myocardial ischemia/reperfusion: damage vs. protection, J. Mol. Cell. Cardiol. 45 .2008; 712. 